\title{
Reply to a comment on "A case for a comet impact trigger for the Paleocene/Eocene thermal maximum and carbon isotope excursion" by G.R. Dickens and J.M. Francis
}

\author{
D.V. Kent ${ }^{\mathrm{a}, \mathrm{b}, *}$, B.S. Cramer ${ }^{\mathrm{a}, \mathrm{c}}$, L. Lanci ${ }^{\mathrm{a}, \mathrm{d}}$, D. Wang ${ }^{\mathrm{e}}$, J.D. Wright ${ }^{\mathrm{a}}$, \\ R. Van der Voo ${ }^{\mathrm{e}}$ \\ a Department of Geological Sciences, Rutgers University, Piscataway, NJ 08854, USA \\ b Lamont-Doherty Earth Observatory, Palisades, NY 10964, USA \\ c Institute of Geology and Paleontology, Tohoku University, Sendai 980-8578, Japan \\ d Instituto di Dinamica Ambientale, Universitá di Urbino, Urbino 61029, Italy \\ e Department of Geological Sciences, University of Michigan, Ann Arbor, MI 48109, USA
}

Received 5 October 2003; received in revised form 7 October 2003; accepted 9 October 2003

Contrary to Dickens and Francis's claim [1] that we "challenge the idea of a massive $\mathrm{CH} 4$ release during the PETM (Paleocene/Eocene thermal maximum)', our consideration of an extraterrestrial carbon contribution to the carbon isotope excursion (CIE) is specifically limited to the initial and most rapid decrease in $\delta^{13} \mathrm{C}$, which accounts for less than half of the full magnitude of the CIE [2]. Thermal dissociation in response to the warming at the PETM is explicitly allowed in our hypothesis, as reiterated in our conclusions that the impact 'may have triggered a more gradual thermal dissociation of seafloor methane hydrates' [2]. We directly challenge only that portion of the hydrate dissociation hypothesis that relies on gradual warming intrinsic to Earth's climate system as the triggering mechanism [3]. Such a mechanism is not consistent with the documented essentially synchronous and instantaneous warming and decrease in $\delta^{13} \mathrm{C}$ values at the onset of the

\footnotetext{
* Corresponding author. Tel.: +1-845-365-8544; Fax: +1-845-365-8158.

E-mail address: dvk@1deo.columbia.edu (D.V. Kent).
}

event $[3,4]$ and is also at odds with the occurrence of the CIE during an interval of low amplitude orbital forcing of climate [5]. Instead, we postulate a comet impact as an explanation for the rapid onset of the event.

Dickens and Francis state that the 'primary difficulty with invoking a comet ... is that there is no supporting evidence' and then list four points from our paper that, taken out of context, are construed as damaging to our hypothesis:

(1) 'There is no crater'. If this were to be taken as a fatal problem with hypothesizing an impact then the idea of a K/T (Cretaceous/Tertiary) impact would never have gained any traction - it took 10 years to identify the smoking gun at Chicxulub crater [6-8]. In addition, it is hardly 'contrived' to acknowledge that the P/E (Paleocene/ Eocene) impact may have occurred on oceanic crust, which constitutes more than half of Earth's surface area and where impact craters of any age have been very difficult to find.

(2) 'The remarkable fossil turnovers ... strongly contrast to those across the Cretaceous/Tertiary Boundary ...' In fact, although we noted that the two events are 'clearly different' [2] and that an a priori assumption that big impacts should be 
associated with mass extinctions is not necessarily valid [9], there may be more parallels between the biotic response at the $\mathrm{P} / \mathrm{E}$ and $\mathrm{K} / \mathrm{T}$ events than are generally acknowledged. The tendency to discount impact as a potential cause of the changes at the P/E boundary seems to stem from an assessment by Kennett and Stott [10] that 'The lack of major extinctions in oceanic plankton and in shallow-water benthic communities eliminates any possibility that the changes were caused by a bolide impact with the Earth [p. 227].' However, the accumulation of data may now point to a different interpretation. Although there is no major extinction in planktonic organisms associated with the PETM, there are dramatic changes in planktonic fossil assemblages, with exotic planktonic foraminifera and calcareous nannoplankton 'excursion taxa' that lived (often as the dominant species) only during the short interval of the PETM [11-14] as well as changes in dinoflagellates [15] that have parallels with the K/T event [16]. Similarities can also be found in the terrestrial record, although the $\mathrm{P} / \mathrm{E}$ boundary interval has yet to be studied in the same detail as the $\mathrm{K} / \mathrm{T}$ : there is evidence for major wildfires [17] that may have occurred precisely at the onset of the event [18] and even contributed significantly to the CIE [19]; a spike in fern spores comparable to that at the $\mathrm{K} / \mathrm{T}$ boundary has been identified in at least one section [17] while at the stratigraphically most well-constrained terrestrial PETM section in the Bighorn Basin of Wyoming, the PETM interval is clearly associated with an abrupt change in the mammalian assemblage [20].

(3) Osmium isotope records do suggest an 'acceleration of continental inputs' that likely resulted from the well-established extended period ( 100 k.y.) of warmth and (possibly) enhanced $\mathrm{pCO}_{2}$ during the PETM. But as we noted [2], the available data are insufficient to determine what happened at the onset of the CIE and any extraterrestrial signature may have been masked by the weathering signal in the low-resolution data of Ravizza et al. [21].

(4) Helium isotopes show no change at the PETM but there is no theoretical reason or empirical evidence that a perturbation in helium isotopes should occur at the time of a large impact (e.g., there is no extraterrestrial helium anomaly at the K/T boundary) [22].

Dickens and Francis also discount the Ir anomaly at Zumaya, claiming that many other elements similarly increase in these samples. The Ir anomaly occurs in a gray layer that also contains elevated concentrations of Ni [23]. Schmitz et al. [23] emphasized the fact that $\mathrm{Fe}$ and Co concentrations within the gray layer are low, but noted elevated concentrations of $\mathrm{Fe}, \mathrm{Co}$, and $\mathrm{Ni}$ in an interval $\sim 6 \mathrm{~cm}$ below this gray layer that they relate to an abundance of glauconized foraminiferal tests. Regarding the other elements measured, Schmitz et al. [23] state that they 'show no unusual concentrations or anomalous abundance peaks in any of the samples analyzed. [p. 56].' Dickens and Francis's contention that 'the Ir ratio to other elements (e.g., Fe) does not vary significantly' is therefore unsubstantiated. In considering their own data, Schmitz et al. [23] give good reasons to rule out abrupt changes in sedimentation rates, precipitation from pore water at a redox barrier, and diffusion from the lower layer that is enriched in $\mathrm{Fe}, \mathrm{Co}$, and $\mathrm{Ni}$, leaving volcanism and impact as the two most likely sources of the Ir enrichment.

Finally, Dickens and Francis take issue with the idea that the high concentrations of single-domain magnetite are derived from an impact. They suggest that an expanded interval of clay-rich sediments deposited at ODP Site 820 on the slope off the Great Barrier Reef on the tropical NE Australian margin during the last transgression (11-7 $\mathrm{ka}$ ) is an analogue of the PETM deposits on the NJ coastal plain in having a high abundance of fine-grained magnetic particles [24]. We measured magnetic hysteresis parameters on samples from Site 820 from the last transgression (seven samples from 4.65 to $6.75 \mathrm{mbsf}$ ) and two earlier transgressions (eight samples from 29.45 to $32.35 \mathrm{mbsf}$ and six samples from 62.85 to $64.95 \mathrm{mbsf}$ ) that also have high magnetizations [24], as well as six samples from an interval with low magnetizations (13.75-18.05 mbsf) using the same techniques described in [2] and compared the results to hysteresis values we reported from the Clayton site (Fig. 1). Transgressive sediments at Site 820 are indeed associated with elevated Msr/Ms values; 


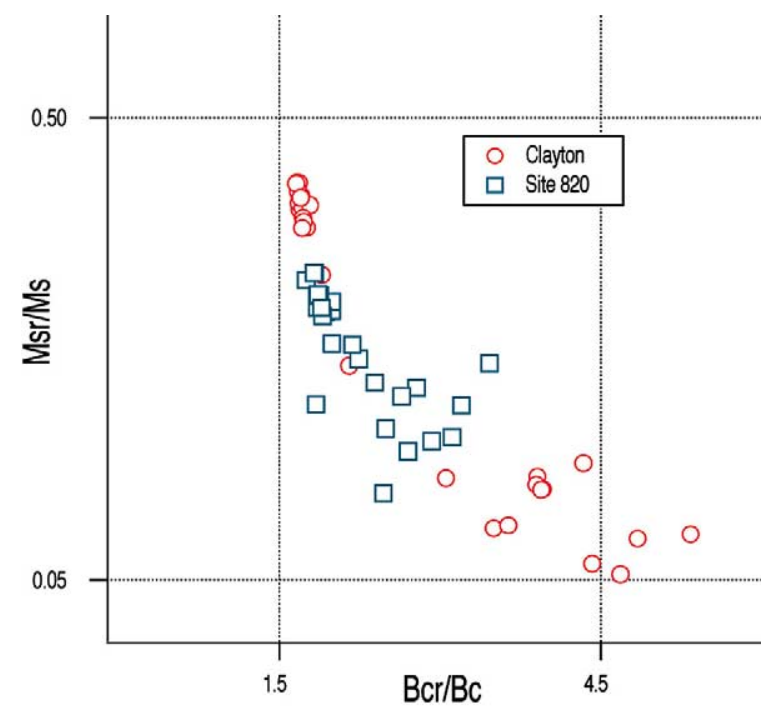

Fig. 1. Comparison of magnetic hysteresis parameters (ratio of saturation remanence to saturation magnetization, Msr/ Ms, versus the ratio of remanent coercivity to coercivity, $\mathrm{Bcr} / \mathrm{Bc}$ ) for samples from across the CIE interval in the Clayton core from NJ coastal plain (see also figure 4 in [2]) and from Neogene transgressive and regressive slope deposits at ODP Site 820 from NE Australian margin (see text for sample intervals).

for example, the seven samples of early to late transgression sediments have a median Msr/Ms ratio of 0.315 . This is consistent with the TEM observations of moderate to high concentrations of chains of single-domain-sized crystals characteristic of biogenically produced magnetite [24]. Measurements on samples from the interval of low magnetizations still have moderate Msr/Ms values that range from 0.189 to 0.261 . However, the Msr/Ms values from Site 820 are clearly intermediate compared to those from across the CIE interval in the Clayton core on the NJ coastal plain, most critically being systematically lower than from the CIE interval (median Msr/Ms ratio of 0.415 for 17 samples) but generally higher than from the enclosing deposits (Fig. 1).

The intermediate range of $\mathrm{Msr} / \mathrm{Ms}$ values at Site 820 suggests that fine-grained magnetite is a substantial component throughout the sedimentary section at Site 820 , and single-domain grains are found in chains as expected for a bacterial origin. Higher concentrations of fine-grain magnetite during transgressions at Site 820 may thus be regarded more as variations on a theme rather than complete changes in regime. On the other hand, we found only isolated single-domain grains in the NJ CIE sediments [2] whose magnetic properties are unique in the late Cretaceous and Cenozoic record of the $\mathrm{NJ}$ coastal plain, in which at least 33 sequences and attendant sea-level changes have been identified $[25,26]$. Indeed, the common occurrence in the CIE sediments of Msr/Ms values greater than 0.4 is highly unusual when compared with published values from a wide range of environments [2], including Site 820 (Fig. 1). Given the sharp grain-size dependency of Msr/Ms values (e.g., [27]), the square-wave character of the magnetic property profiles and high Msr/Ms values imply that the normal magnetic component of the sediments must have been largely excluded, emphasizing that a radically different sedimentary regime occurred at the onset of the CIE in the NJ sections. We suggest that these observations of the CIE interval on the NJ coastal plain are better explained by the presence of abundant magnetic nanoparticles in ejecta dust that was redeposited as kaolinitic clays on the marine shelf.

In conclusion, we agree with Dickens and Francis that it is important to stress the fundamental problems with any hypothesis; indeed consideration of two fundamental problems with the hydrate dissociation hypothesis led us to consider the possibility of an impact: (1) the lack of a plausible triggering mechanism to initiate dissociation [28], and (2) in order to account for the full magnitude of the CIE the proportion of sediment pore space filled by hydrate must have been significantly higher than in the modern continental margin (see [29]), which is physically unlikely [30]. Our proposal of a comet impact trigger addresses both of these problems, providing an additional source of isotopically light carbon to supplement methane from hydrates and a testable triggering mechanism that would have resulted in simultaneous and instantaneous warming and initial decrease in $\delta^{13} \mathrm{C}$ values. We believe that: (1) abundant magnetic nanoparticles, (2) an Ir anomaly, and (3) the extremely rapid shift in carbon isotope values can all be viewed as supportive evidence for the impact of an extraterrestrial object. We know of only two lines of evidence that have 
been used to support release of hydrate at the onset of the CIE: (1) the magnitude of the CIE [31], and (2) slumping along the North American Atlantic continental margin [32], which we note could be triggered by an impact event and may be a more effective mechanism for rapid release of hydrate than thermal dissociation [28]. We thus find considerable irony in Dickens and Francis's statement that 'there is zero incontrovertible evidence for a comet impact across the PETM' surely the evidence for hydrate dissociation is no more incontrovertible than for a comet impact trigger.

\section{Acknowledgements}

We thank the Curator and staff of the ODP Gulf Coast Repository at Texas A\&M University for providing samples from Site 820 on short notice and Ken Miller and Miriam Katz for constructive comments on the manuscript. Sponsored by NSF grant OCE 0084032. LDEO contribution \#6528.[BARD]

\section{References}

[1] G.R. Dickens, J.M. Francis, Comment on 'A case for a comet impact trigger for the Paleocene/Eocene thermal maximum and carbon isotope excursion', Earth Planet. Sci. Lett. 217 (2003), doi: 10.1016/j.epsl.2003.10.003.

[2] D.V. Kent, B.S. Cramer, L. Lanci, D. Wang, J.D. Wright, R. VanderVoo, A case for a comet impact trigger for the Paleocene/Eocene thermal maximum and carbon isotope excursion, Earth Planet. Sci. Lett. 211 (2003) 13-26.

[3] D.J. Thomas, J.C. Zachos, T.J. Bralower, E. Thomas, S. Bohaty, Warming the fuel for the fire: Evidence for the thermal dissociation of methane hydrate during the Paleocene-Eocene thermal maximum, Geology 30 (2002) 10671070.

[4] S. Bains, R.M. Corfield, R.D. Norris, Mechanism of climate warming at the end of the Paleocene, Science 285 (1999) 724-727.

[5] B.S. Cramer, J.D. Wright, D.V. Kent, M.-P. Aubry, Orbital climate forcing of $\delta^{13} \mathrm{C}$ excursions in the late Paleocene-early Eocene (Chrons C24n-C25n), Paleoceanography (2003) doi:10.1029/2003PA000909.

[6] L.W. Alvarez, W. Alvarez, F. Asaro, H.V. Michel, Extraterrestrial cause for the Cretaceous-Tertiary extinction, Science 208 (1980) 1095-1108.

[7] A.R. Hildebrand, G.T. Penfield, D.A. Kring, M. Pilking- ton, A. Camargo, S.B. Jacobsen, W.V. Boynton, Chicxulub crater: A possible Cretaceous/Tertiary boundary impact crater on the Yucatan Peninsula, Mexico, Geology 19 (1991) 867-971.

[8] C.C. Swisher, J.M. Grajales-Nishimura, A. Montanari, S.V. Margolis, P. Claeys, W. Alvarez, P. Renne, E. Cedillo-Pardo, F.L.M.R. Maurasse, G.H. Curtis, J. Smit, M.O. McWilliams, Coeval ${ }^{40} \mathrm{Ar} /{ }^{39} \mathrm{Ar}$ ages of 65.0 million years ago from Chicxulub crater melt rock and Cretaceous-Tertiary boundary tektites, Science 257 (1992) 954-958.

[9] C.W. Poag, Roadblocks on the kill curve: Testing the Raup hypothesis, Palaios 12 (1997) 582-590.

[10] J.P. Kennett, L.D. Stott, Abrupt deep-sea warming, palaeoceanographic changes and benthic extinctions at the end of the Palaeocene, Nature 353 (1991) 225-229.

[11] T.J. Bralower, Evidence of surface water oligotrophy during the Paleocene-Eocene thermal maximum: Nannofossil assemblage data from Ocean Drilling Program Site 690, Maud Rise, Weddell Sea, Paleoceanography 17 (2002) doi:10.1029/2001PA000662.

[12] D.C. Kelly, T.J. Bralower, J.C. Zachos, I. Premoli-Silva, E. Thomas, Rapid diversification of planktonic foraminifera in the tropical Pacific (ODP Site 865) during the late Paleocene thermal maximum, Geology 24 (1996) 423-426.

[13] B.S. Cramer, M.-P. Aubry, K.G. Miller, R.K. Olsson, J.D. Wright, D.V. Kent, An exceptional chronologic, isotopic, and clay mineralogic record of the latest Paleocene thermal maximum, Bass River, NJ, ODP 174AX, Bull. Soc. Géol. France 170 (1999) 883-897.

[14] M.P. Aubry, A. Sanfilippo, Late Paleocene-Early Eocene sedimentary history in western Cuba: Implications for the LPTM and for regional tectonic history, Micropaleontology 45 (1999) 5-18.

[15] E.M. Crouch, C. Heilmann-Clausen, H. Brinkhuis, H.E.G. Morgans, K.M. Rogers, H. Egger, B. Schmitz, Global dinoflagellate event associated with the late Paleocene thermal maximum, Geology 29 (2001) 315-318.

[16] H. Brinkhuis, E.M. Crouch, Cretaceous/Tertiary and Paleocene/Eocene parallels; a dinoflagellate perspective, in: A.W. Ash, S.L. Wing (Eds.), Climate and Biota of the Early Paleogene, International Meeting, July 3-8, 2001, Abstr. Vol. 17, Smithsonian Institution, Washington, DC, Powell, WY, 2001.

[17] M.E. Collinson, J.J. Hooker, D.R. Gröcke, Cobham Lignite Bed and penecontemporaneous macrofloras of southern England: A record of vegetation and fire across the Paleocene-Eocene Thermal Maximum, in: S.L. Wing, P.D. Gingerich, B. Schmitz, E. Thomas (Eds.), Causes and Consequences of Globally Warm Climates in the Early Paleogene, Geol. Soc. Am. Spec. Pap. 369, Geol. Soc. Am., Boulder, CO, 2003, pp. 335-350.

[18] K. Kaiho, M. Nakamura, B.S. Cramer, A.M. Hussein, M.A. Lamolda, Extensive fires immediately preceded the extreme warming and benthic extinction event at the $\mathrm{Pa}-$ leocene/Eocene boundary (abstract), in: M.A. Lamolda (Ed.), Bioevents: Their Stratigraphic Records, Patterns 
and Causes, June 3-8, 2003, Caravaca de la Cruz, Spain, 2003, p. 114.

[19] A.C. Kurtz, L.R. Kump, M.A. Arthur, J.C. Zachos, A. Paytan, Early Cenozoic decoupling of the global carbon and sulfur cycles, Paleoceanography 18 (2003) doi: 10.1029/2003PA000908.

[20] P.D. Gingerich, Mammalian responses to climate change at the Paleocene-Eocene boundary: Polecat Bench record in the northern Bighorn Basin, Wyoming, in: S.L. Wing, P.D. Gingerich, B. Schmitz, E. Thomas ( Eds.), Causes and Consequences of Globally Warm Climates in the Early Paleogene, Geol. Soc. Am. Spec. Pap. 369, Geol. Soc. Am., Boulder, Colorado, 2003, pp. 463-478.

[21] G. Ravizza, R.N. Norris, J. Blusztajn, M.-P. Aubry, An osmium isotope excursion associated with the late Paleocene thermal maximum: Evidence of intensified chemical weathering, Paleoceanography 16 (2001) 155-163.

[22] K.A. Farley, Cenozoic variations in the flux of interplanetary dust recorded by ${ }^{3} \mathrm{He}$ in a deep-sea sediment, Nature 376 (1995) 153-156.

[23] B. Schmitz, F. Asaro, E. Molina, S. Monechi, K. vonSalis, R.P. Speijer, High-resolution iridium, $\delta^{13} \mathrm{C}, \delta^{18} \mathrm{O}$, foraminifera and nannofossil profiles across the latest $\mathrm{Pa}$ leocene benthic extinction event at Zumaya, Spain, Palaeogeogr. Palaeoclimatol. Palaeoecol. 133 (1997) 4968.

[24] C.E. Barton, M. Lackie, F.M. Peerdeman, Environmental control of magnetic properties of upper-slope sediments ear the Great Barrier Reef: Results from Leg 133, Proc. Ocean Drill. Prog. Sci. Results 133 (1993) 543-562.

[25] L. Lanci, D.V. Kent, K.G. Miller, Detection of sequence boundaries using core-log integration of magnetic susceptibility and natural gamma-ray measurements at the Ancora site on the Atlantic Coastal Plain, J. Geophys. Res. 107 (2002) doi:10.1029/2000JB000026.

[26] K.G. Miller, G.S. Mountain, J.V. Browning, M. Kominz, P.J. Sugarman, N. Christie-Blick, M.E. Katz, J.D. Wright, Cenozoic global sea level, sequences, and the New Jersey Transect: results from coastal plain and continental slope drilling, Rev. Geophys. 36 (1998) 569-601.

[27] L. Lanci, D.V. Kent, Introduction of thermal activation in forward modeling of hysteresis loops for single-domain magnetic particles and implications for the interpretation of the Day diagram, J. Geophys. Res. 108 (2003) 3/1-3/9.

[28] M.E. Katz, B.S. Cramer, G.S. Mountain, S. Katz, K.G. Miller, Uncorking the bottle: What triggered the Paleocene/Eocene thermal maximum methane release?, Paleoceanography 16 (2001) 549-562.

[29] G.R. Dickens, The potential volume of oceanic methane hydrates with variable external conditions, Org. Geochem. 32 (2001) 1179-1193.

[30] M.K. Davie, B.A. Buffett, A numerical model for the formation of gas hydrate below the seafloor, J. Geophys. Res. 106 (2001) 497-514.

[31] G.R. Dickens, J.R. O'Neil, D.K. Rea, R.M. Owen, Dissociation of oceanic methane hydrate as a cause of the carbon isotope excursion at the end of the Paleocene, $\mathrm{Pa}$ leoceanography 10 (1995) 965-971.

[32] M.E. Katz, D.K. Pak, G.R. Dickens, K.G. Miller, The source and fate of massive carbon input during the latest Paleocene thermal maximum, Science 286 (1999) 15311533. 